MHERISEOF

INEARLYMEDIEVALEUROPE 



\section{THE RISE OF}

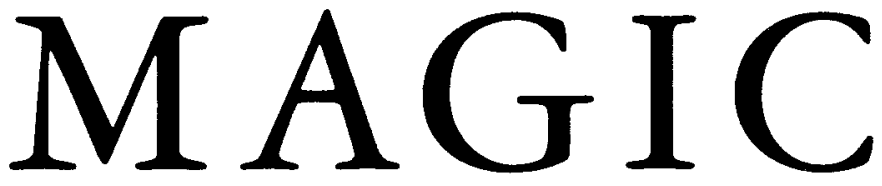

In Early Medieval Europe

Valerie I. J. Flint

PRINCETON UNIVERSITY PRESS - PRINCETON, NEW JERSEY 
Copyright (C) r99 I by Princeton University Press

Published by Princeton University Press, 4I William Street,

Princeton, New Jersey o8540

All Rights Reserved

Library of Congress Cataloging-in-Publication Data

Flint, Valerie I. J. (Valerie Irene Jane), I936-

The rise of magic in early medieval Europe / Valerie I. J. Flint.

p. $\mathrm{cm}$.

Includes bibliographical references.

ISBN $0-69$ I -03 I $65-7$

ISBN o-69 I-00 I 10-3 (pbk.)

I. Magic-Europe-History. 2. Europe-Religious life and customs.

3. Church history-Middle Ages, 600-1 500. 4. Civilization, Medieval. I. Title.

$\mathrm{BF}_{1593} \mathrm{~F}_{45} \quad$ 1990

I $33.4^{\prime} 3^{\prime} 0940902-\mathrm{dc} 20 \quad 90-34843$

This book has been composed in Linotron Goudy Old Style

Princeton University Press books are printed on acid-free paper and meet the guidelines for permanence and durability of the Committee on Production Guidelines for Book Longevity of the Council on Library Resources

Printed in the United States of America

First Princeton Paperback printing, 1994

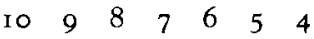


To the Memory of My Mother IRENE A.B F FINT 
